\title{
Helminth parasites of Phyllodactylidae and Gekkonidae lizards in a Caatinga ecological station, northeastern Brazil
}

\author{
Vandeberg F. Lima ${ }^{1 *}$, Samuel V. Brito ${ }^{4}$, João A. Araujo Filho², Diêgo A. Teles ${ }^{2}$, Samuel C. Ribeiro \\ Adonias A. M. Teixeira ${ }^{2}$, Antonio M. A. Pereira ${ }^{1}$, Waltécio O. Almeida ${ }^{I}$ \\ ${ }^{1}$ Programa de Pós-Graduação em Bioprospecção Molecular, Departamento de Química Biológica, Universidade \\ Regional do Cariri-URCA, Rua Cel. Antônio Luiz, 1161, Campus do Pimenta, 63105-000 Crato, CE, Brazil \\ ${ }^{2}$ Programa de Pós-Graduação em Ciências Biológicas (Zoologia), Departamento de Sistemática e Ecologia - DSE, \\ Centro de Ciências Exatas e da Natureza - CCEN, Universidade Federal da Paraíba - UFPB, Cidade Universitária, \\ Campus I, 58059-900 João Pessoa, PB, Brazil \\ ${ }^{3}$ Instituto de Formação de Educadores - IFE, Universidade Federal do Cariri - UFCA, Campus Brejo Santo, \\ 63260-000 Brejo Santo, CE, Brazil \\ ${ }^{4}$ Centro de Ciências Agrárias e Ambientais, Universidade Federal do Maranhão - UFMA, Boa Vista, 65500-000 \\ Chapadinha, MA, Brazil \\ *Corresponding author: Vandeberg F. Lima, e-mail: vandeberglima@hotmail.com
}

LIMA, V. F., BRITO, S. V., ARAUJO FILHO, J. A., TELES, D. A., RIBEIRO, S. C., TEIXEIRA, A. A. M., PEREIRA, A. M. A., ALMEIDA, W. O. Helminth parasites of Phyllodactylidae and Gekkonidae lizards in a Caatinga ecological station, northeastern Brazil. Biota Neotropica. 17(4): e20160263. http://dx.doi.org/10.1590/1676-0611-BN-2016-0263

\begin{abstract}
We investigated the parasites of five lizard species belonging to Phyllodactylidae (Phyllopezus pollicaris and Gymnodactylus geckoides) and Gekkonidae (Hemidactylus agrius, Lygodactylus klugei and Hemidactylus brasilianus) families in a semiarid region of Brazil. Six nematode species were identified: Parapharyngodon alvarengai and Spauligodon oxkutzcabiensis (Pharyngodonidae), Physaloptera lutzi (Physalopteridae), Skrjabinelazia intermedia (Seuratidae), Trichospirura sp. (Rhabdochonidae) and Piratuba sp. (Onchocercidae), and a cestode species, Oochoristica sp. (Linstowiidae). The most prevalent species were Spauligodon oxkutzcabiensis, which infected P. pollicaris (75\%), and Parapharyngodon alvarengai, which infected G. geckoides (29\%). South American lizards were identified as being new hosts for the Trichospirura genus (a usual parasite of mammals), and there were 16 new occurrences of parasite species in the five lizard species studied herein.
\end{abstract}

Keywords: Squamata, Nematoda, Cestoda, geckos, semiarid

\section{Helmintos parasitas de lagartos Phyllodactylidae e Gekkonidae em estação ecológica na Caatinga, nordeste do Brasil}

Resumo: Nós investigamos os parasitas de cinco espécies de lagartos pertencentes às famílias Phyllodactylidae (Phyllopezus pollicaris e Gymnodactylus geckoides) e Gekkonidae (Hemidactylus agrius, Lygodactylus klugei e Hemidactylus brasilianus) em região semiárida do Brasil. Seis espécies de nematoides foram encontrados: Parapharyngodon alvarengai e Spauligodon oxkutzcabiensis (Pharyngodonidae), Physaloptera lutzi (Physalopteridae), Skrjabinelazia intermedia (Seuratidae), Trichospirura sp. (Rhabdochonidae), Piratuba sp. (Onchocercidae) e uma espécie de cestódeo, Oochoristica sp. (Linstowiidae). As espécies de maiores prevalências foram S. oxkutzcabiensis, a qual infectou P. pollicaris (75\%) e P. alvarengai a qual infectou G. geckoides (29.\%). Nós documentamos novo registro de hospedeiro para lagartos na América do Sul pertencente ao gênero Trichospirura, o qual é comum em mamíferos, e 16 novas ocorrências de espécies parasitas nas cinco espécies de lagartos aqui estudadas.

Palavras chave: Squamata, Nematoda, Cestoda, geckos, semiárido 


\section{Introduction}

Helminths are parasites that infect the internal and external organs of most invertebrate and vertebrate groups (Fergunson 1942; Round 1968; Salgado-Maldonado et al. 2005; Hamann et al. 2006a, b; Ávila et al. 2012). Among this wide diversification of hosts, there is a great diversity of parasites in South American lizards (Ávila \& Silva 2010), and several studies have recorded variation in parasite richness and diversity (Bursey \& Goldberg 2004; Bursey et al. 2005; Anjos et al. 2013; Araujo-Filho et al. 2014; Brito et al. 2014a, b; Galdino et al. 2014; Sousa et al. 2014).

Knowledge of the lizard-associated helminth fauna has increased through research concerning (i) records of new hosts (Bursey \& Goldberg 2004; Bursey et al. 2005; Ávila \& Silva 2010; McAllister et al. 2011; Ávila et al. 2012), (ii) descriptions of new parasite species (Bursey et al. 2003; Pereira et al. 2012), and (iii) influence of biotic and abiotic variables on helminth diversity and abundance (Sharpilo et al. 2001; Brito et al. 2014a, b; Galdino et al. 2014).

Phyllodactylidae and Gekkonidae are two lizard families of the Gekkota clade that are phylogenetically closely related taxa (Sites et al. 2011). Both families occur in Brazil with, respectively, 13 and six nominal species (Costa \& Bérnils 2015), and only Gymnodactylus geckoides Spix, 1825, Phyllopezus periosus Rodrigues, 1986, Phyllopezus pollicaris (Spix, 1825) (Phyllodactylidae), Hemidactylus mabouia Moreau de Jonnes, 1818, and Hemidactylus agrius Vanzolini, 1978 (Gekkonidae) occur within the Caatinga biome. Hemidactylus brasilianus (Amaral, 1935) and Lygodactylus klugei (Smith, Martin \& Swain, 1977) (Gekkonidae) often inhabit the Caatinga biome (Vitt 1995; Rocha et al. 2011; Andrade et al. 2013). These species are sit-and-wait foragers, have nocturnal habits (except for the diurnal L. klugei) and an insectivore diet (Vitt 1995; Colli et al. 2003; Rocha \& Rodrigues 2005; Mesquita et al. 2006; Sousa 2010; Recorder et al. 2012; Albuquerque et al. 2013; Passos \& Rocha 2013; Passos et al. 2015). The studies reporting helminth parasitism in South America for both families have been conducted by Anjos et al. (2005), Ávila \& Silva (2010), Ávila et al. (2010), Ávila \& Silva (2013), Brito et al. (2014a), Sousa et al. (2014), Cazorla \& Morales Moreno (2015) and Bezerra et al. (2016).

Parasites are good indicators of healthy ecosystems, which is essential to studies of conservation and maintenance of host populations (Marcogliese 2004, 2005), which may reflect the anthropic influence in the environment in which they reside (Hamman et al. 2006b). Thus, characterization of the parasite population of a certain area of the Caatinga biome is essential, especially for future studies on species conservation.

The current study characterizes the helminth richness of parasitic species and the parameters of parasitic infection (prevalence, mean intensity of infection and range) in lizards of the Phyllodactylidae and Gekkonidae families collected at the Aiuaba Ecological Station, northeastern Brazil.

\section{Material and Methods}

Lizards were collected at the Aiuaba Ecological Station (ESEC Aiuaba), municipality of Aiuaba, state of Ceará, northeastern Brazil (6 36'27'S and $40^{\circ} 08^{\prime} 00.9^{\prime \prime} \mathrm{W}, 466 \mathrm{~m}$ asl, datum SIRGAS 2000) (Figure 1). The sampled area is within the Caatinga biome, which is characterized by xerophytic plants, shrubs, thorny trees and open areas (Andrade-Lima 1981). The climate in this biome is semiarid, hot tropical, with an average annual rainfall of $562.4 \mathrm{~mm}$, average temperature ranging from $24^{\circ} \mathrm{C}$ to $26^{\circ} \mathrm{C}$ and a rainy season from February to April (IPECE 2015).

We conducted manual collections through active searching over four sampling expeditions, two in 2014 (September and November) and two in 2015 (February and April) with authorization provided by the "Sistema de Autorização e Informação em Biodiversidade” (SISBIO order number 43753-1). The lizards were euthanized with a lidocaine lethal dose. Their snout-vent length (SVL) was measured with a digital caliper $( \pm 0.01 \mathrm{~mm})$. Thereafter they were labelled, fixed with $10 \%$ formaldehyde and preserved in $70 \%$

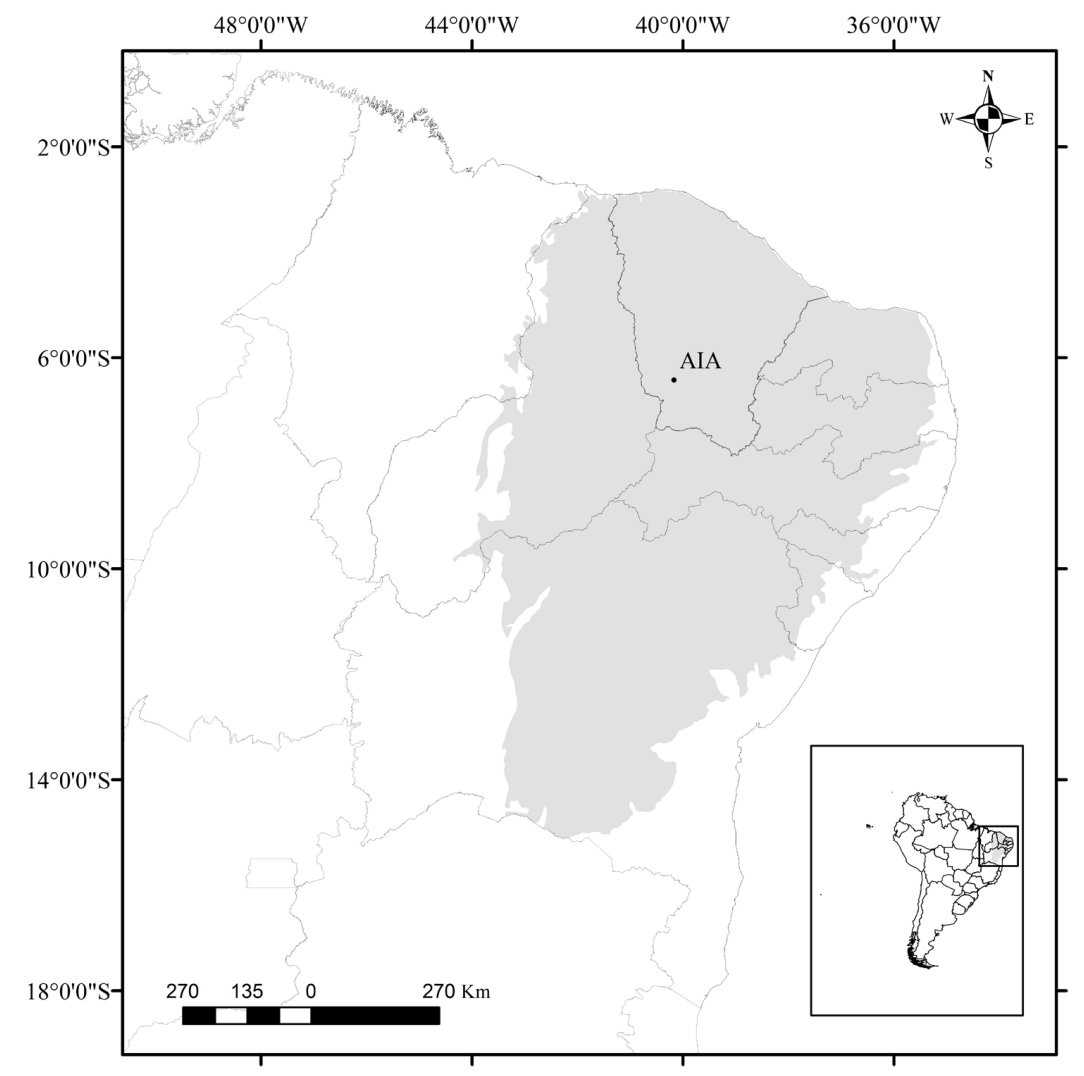

Figure 1. Geographic map featuring the Aiuaba Ecological Station (AIA), state of Ceará, northeastern Brazil. In gray, the Caatinga biome as conceived by IBGE (2004). 
ethyl alcohol. Lizard specimens were deposited in the Herpetological Collection of the Regional University of Cariri, municipality of Crato, state of Ceará, Brazil. The hosts were dissected under a stereomicroscope and their body cavity, lung, stomach, small intestine and large intestine was analyzed in search of helminths. The lizard's gonads were analyzed to determine their gender and sexual maturity. We considered as mature males those with developed testicles and a convoluted epididymis, and as mature females those that had vitellogenic follicles in their oviducts and/ or eggs in their ovaries.

The nematodes were cleared in a Hoyer solution and the cestodes were colored in Carmim and cleared in a Hoyer solution as well for identification (Everhart 1957). The parasites were mounted on temporary slides for identification, and their morphology was compared with specimens present in the parasitological collection of the Universidade Regional do Cariri - URCAP, and bibliographic reference on the description of the parasite species found that did not have specimens in the collection. Subsequently, they were deposited in the Parasitological Collection of the Regional University of Cariri (Appendix 1). The prevalence and the mean intensity of infection for each endoparasite species were calculated for each lizard species according to Bush et al. (1997).

\section{Results}

We sampled a total of 355 lizards specimens, distributed in the five focused species of this study. Phyllodactylidae: Phyllopezus pollicaris, 132 specimens, 57 males $(\mathrm{SVL}=64.2 \pm 8.4 \mathrm{~mm})$ and 75 females $(\mathrm{SVL}=62.5 \pm 11.9 \mathrm{~mm})$; Gymnodactylus geckoides, 71 specimens, 30 males ( $\mathrm{SVL}=37.7 \pm 3.7 \mathrm{~mm})$ and 41 females $(\mathrm{SVL}=37.5 \pm 4.1 \mathrm{~mm})$. Gekkonidae: Hemidactylus agrius, 63 specimens, 28 males $(\mathrm{SVL}=47.1 \pm 3.8 \mathrm{~mm})$ and 35 females $(\mathrm{SVL}=47.8 \pm 3.7 \mathrm{~mm})$; Lygodactylus klugei, 65 specimens, 25 males $(\mathrm{SVL}=27.5 \pm 2.5 \mathrm{~mm})$ and 40 females $(\mathrm{SVL}=28.1 \pm 2.4 \mathrm{~mm})$; and Hemidactylus brasilianus, 24 specimens, 11 males $(\mathrm{SVL}=45 \pm 5.9 \mathrm{~mm})$ and 13 females $(\mathrm{SVL}=43.6 \pm 5.7 \mathrm{~mm})$. All lizards were in full sexual maturity.

We found six nematode species [Parapharyngodon alvarengai Freitas, 1957, Spauligodon oxkutzcabiensis (Chitwood, 1938), Physaloptera lutzi Cristofaro, Guimarães \& Rodrigues, 1976, Skrjabinelazia intermedia Freitas, 1940, Trichospirura sp. Smith \& Chitwood, 1967 and Piratuba sp. Lent \& Freitas, 1941] and one cestode of the genus Oochoristica Lühe, 1898 that could not be identified at the species level (Table 1).

Helminth parasites found in this study have different life cycles. While P. lutzi, Oochoristica sp., Piratuba sp., Trichospirura sp. and S. intermedia

Table 1. Helminth parasites collected in lizards belonging to Phyllodactylidae and Gekkonidae families from the Aiuaba Ecological Station, municipality of Aiuaba, state of Ceará, northeastern Brazil. Number of Infected hosts $=(\mathrm{NI})$, Prevalence $=$ P (\%), Mean Intensity of Infection $=$ MII and Range (R). $(*)$ New records of hosts.

\begin{tabular}{|c|c|c|c|c|}
\hline Parasite & Location in host & Host (NI) & $\mathbf{P}(\%)$ & MII (R) \\
\hline \multicolumn{5}{|l|}{ NEMATODA } \\
\hline \multicolumn{5}{|l|}{ Pharyngodonidae } \\
\hline \multirow[t]{4}{*}{ Parapharyngodon alvarengai } & large intestine & Phyllopezus pollicaris (6) & $4.54 \%$ & $1.33(1-2)$ \\
\hline & large intestine & Hemidactylus brasilianus*(2) & $8.33 \%$ & $1(1)$ \\
\hline & small intestine; large intestine & Hemidactylus agrius (8) & $12.69 \%$ & $1.87(1-4)$ \\
\hline & small intestine; large intestine & Gymnodactylus geckoides (21) & $29.57 \%$ & $1.66(1-5)$ \\
\hline \multirow[t]{5}{*}{ Spauligodon oxkcutzcabiensis } & small intestine; large intestine & Phyllopezus pollicaris (99) & $75 \%$ & $26.02(270)$ \\
\hline & large intestine & Hemidactylus brasilianus* (2) & $8.33 \%$ & $5.5(3-8)$ \\
\hline & large intestine & Hemidactylus agrius* $(11)$ & $17.46 \%$ & $1.9(1-4)$ \\
\hline & large intestine & Gymnodactylus geckoides (1) & $1.40 \%$ & $18(18)$ \\
\hline & large intestine & Lygodactylus klugei*(4) & $6.15 \%$ & $3(1-9)$ \\
\hline \multicolumn{5}{|l|}{ Physalopteridae } \\
\hline \multirow[t]{5}{*}{ Physaloptera lutzi } & stomach; large intestine & Phyllopezus pollicaris* (4) & $3.03 \%$ & $1.25(1-2)$ \\
\hline & stomach & Hemidactylus brasilianus* (1) & $4.16 \%$ & $1(1)$ \\
\hline & stomach & Hemidactylus agrius (1) & $1.58 \%$ & $6(6)$ \\
\hline & stomach; large intestine & Gymnodactylus geckoides (9) & $12.67 \%$ & $2(1-4)$ \\
\hline & stomach & Lygodactylus klugei (1) & $1.53 \%$ & $1(1)$ \\
\hline \multicolumn{5}{|l|}{ Seuratidae } \\
\hline \multirow{3}{*}{ Skrjabinelazia intermedia } & small intestine; large intestine & Phyllopezus pollicaris* ${ }^{*}(1)$ & $0.75 \%$ & $2(2)$ \\
\hline & large intestine & Hemidactylus brasilianus* (4) & $16.66 \%$ & $1.25(1-2)$ \\
\hline & large intestine & Hemidactylus agrius* $(17)$ & $26.98 \%$ & $1.64(1-4)$ \\
\hline \multicolumn{5}{|l|}{ Rhabdochonidae } \\
\hline \multirow[t]{4}{*}{ Trichospirura sp. } & gallbladder & Phyllopezus pollicaris* (13) & $9.84 \%$ & $3.69(1-11)$ \\
\hline & gallbladder & Hemidactylus brasilianus* (2) & $8.33 \%$ & $3.5(2-5)$ \\
\hline & gallbladder & Hemidactylus agrius* ${ }^{*}(12)$ & $19.04 \%$ & $2.58(1-7)$ \\
\hline & gallbladder & Gymnodactylus geckoides* (4) & $5.63 \%$ & $1.5(1-3)$ \\
\hline \multicolumn{5}{|l|}{ Onchocercidae } \\
\hline Piratuba sp. & body cavity & Gymnodactylus geckoides* (1) & $1.40 \%$ & $1(1)$ \\
\hline \multicolumn{5}{|l|}{ CESTODA } \\
\hline \multicolumn{5}{|l|}{ Linstowiidae } \\
\hline \multirow[t]{3}{*}{ Oochoristica sp. } & small intestine & Phyllopezus pollicaris (2) & $1.51 \%$ & $1.5(1-2)$ \\
\hline & small intestine & Hemidactylus brasilianus* (1) & $4.16 \%$ & $2(2)$ \\
\hline & small intestine & Hemidactylus agrius* $(1)$ & $1.58 \%$ & $1(1)$ \\
\hline
\end{tabular}




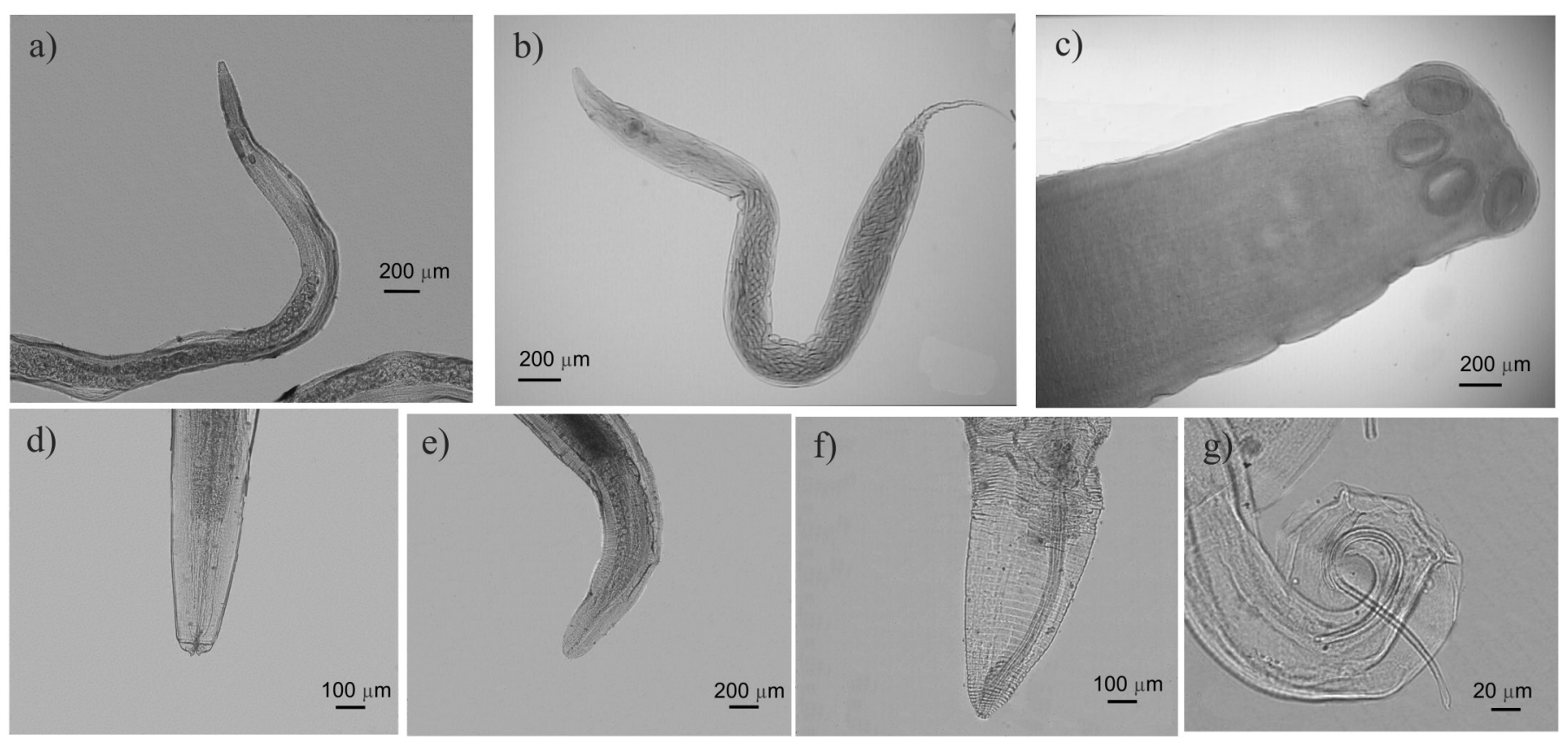

Figure 2. Helminths of the gastrointestinal tract of geckos from the Aiuaba Ecological Station (AIA), state of Ceará, northeastern Brazil: (a) Skrjabinelazia intermedia (posterior view); (b) Spauligodon oxkutzcabiensis (entire specimen); (c) Oochoristica sp. (anterior view); (d) Physaloptera lutzi (anterior view); (e) Piratuba sp. (anterior view); (f) Parapharyngodon alvarengai (anterior view); (g) Trichospirura sp. (posterior view).

have heteroxenic life cycles, which requires more than one host to complete its life cycle, $P$. alvarengai and $S$. oxkutzcabiensis have monoxenic life cycles, not requiring more than one host (Illgen-Wilcke et al. 1992, Anderson, 2000, Lhermitte et al. 2007) (Figure 2).

\section{Discussion}

Among the parasite species identified, there were 16 new records of hosts distributed among the five lizard species sampled in this study. We found three parasite species in P. pollicaris, four in H. agrius, two in G. geckoides, six in H. brasilianus and one in L. klugei.

Spauligodon oxkutzcabiensis was first recorded with Thecadactylus rapicauda (Houttuyn, 1782) (Phyllodactylidae). In South America, S. oxkutzcabiensis was recorded in association with the following lizards (Ávila et al. 2010; Goldberg et al. 2010; Goldberg \& Bursey 2010; Sousa et al. 2014): G. geckoides, Hemidactylus mabouia (Moreau de Jonnès, 1818), Microlophus occipitalis (Peters, 1871), Phyllodactylus reissi (Peters, 1862), P. inaequalis Cope, 1876, P. johnwrighti Dixon \& Huey, 1970, P. microphyllus (Cope, 1876), Phyllopezus lutzae (Loveridge, 1941) [= Bogertia lutzae] and Tropidurus guarani Alvarez, Cei \& Scolaro, 1991 [= T. spinulosus]. Spauligodon oxkutzcabiensis was present in all five lizard species sampled in this research. It is, therefore, considered here as the lizard's generalist endoparasite for Phyllodactylidae and Gekkonidae, adding $H$. agrius, $H$. brasilianus and $L$. klugei to the list of new records of hosts.

Parapharyngodon alvarengai was recorded as being hosted by Ameivula ocellifera (Spix, 1825) [= Cnemidophorus ocellifer], Ameiva ameiva (Linnaeus, 1758), Amphisbaena ridleyi Boulenger, 1890, Brasiliscincus heathi (Schmidt \& Inger, 1951), G. geckoides, Phyllopezus pollicaris, P. periosus, Trachylepis atlantica (Schmidt, 1945), Tropidurus hispidus (Spix, 1825), T. semitaeniatus (Spix, 1825) and Hemidactylus agrius Vanzolini, 1978 (Anjos et al. 2011; Ávila et al. 2012; Brito et al. 2014b). We observed $P$. alvarengai infecting $P$. pollicaris, G. geckoides, H. agrius and $H$. brasilianus.
Physaloptera lutzi infected all lizards sampled in the current study. Although it had been originally described as a parasite of A. ameiva, we recorded both $P$. pollicaris and $H$. brasilianus as new hosts for this species. Other records of hosts for $P$. lutzi were also reported in the literature (Anjos et al. 2011; Ávila et al. 2010, 2012; Brito et al. 2014b): Ameivula abaetensis (Dias, Rocha \& Vrcibradic, 2002) [= Cnemidophorus abaetensis], Ameivula littoralis (Rocha, Araújo, Vrcibradic \& Costa, 2000) [= Cnemidophorus littoralis], A. ocellifera, Enyalius bilineatus Duméril \& Bibron, 1837, Eurolophosaurus nanuzae (Rodrigues, 1981), Liolaemus alticolor Barbour, 1909, L. ornatus Koslowsky, 1898, L. quilmes Etheridge, 1993, Tropidurus guarani, T. semitaeniatus, T. hispidus, T. itambere Rodrigues, 1987, T. torquatus (Wied, 1820), H. agrius, L. klugei, G. geckoides, Micrablepharus maximiliani (Reinhardt \& Lütken, 1862) and Salvator merianae (Duméril \& Bibron, 1839) [= Tupinambis merianae]. Given that $P$. lutzi has a heteroxenic life cycle, its intermediate host is probably a food item that is consumed by all sampled lizards in our study area.

Regarding the Trichospirura genus, our data revealed P. pollicaris, G. Geckoides, H. agrius and H. brasilianus lizards as new host records for South America. Only primates from the following genera had been previously recorded as hosts for Trichospirura: Callicebus Thomas, 1903 (Orihel \& Seibold 1971; Pacheco et al. 2003), Callithrix Erxleben, 1777 (Smith \& Chitwood 1967; Resende et al. 1994), Saimiri Voigt, 1831 (Orihel \& Seibold 1971), Aotus Illiger, 1811 (Orihel \& Seibold 1971), Callimico Miranda Ribeiro, 1922 (Orihel \& Seibold, 1971) and Saguinus Hoffmannsegg, 1807 (Cosgrove et al. 1968).

The Skrjabinelazia genus was found infecting geckos (Lhermitte et al. 2007; Anjos et al. 2011). Nevertheless, records for S. intermedia were restricted so far to a teid Ameivula nativo (Rocha, Bergallo \& Peccinini-Seale, 1997) [= Cnemidophorus nativo] (Menezes et al. 2004), twice in Tropiduridae [Tropidurus torquatus and T. guarani, Vicente et al. 1993] and once for Dactyloidae Dactyloa punctata (Daudin, 1802) [= Anolis punctatus] (Ávila \& Silva 2010). Our data provided three host records for $S$. intermedia: P. pollicaris, $H$. agrius, and $H$. brasilianus. 
Little is known about the biology of the genus Oochoristica. Most studies on the genus were limited to describe new species and record new hosts (Ávila \& Silva 2010; Brito et al. 2014b; Sousa et al. 2014). Our study reports three records of hosts (P. pollicaris, H. agrius and H. brasilianus) with two new infection records for the genus Oochoristica.

Piratuba is a genus that belongs to the Onchocercidae family. It has a widespread distribution throughout South America, in which other studies reported that lizards from the genera Tropidurus, Kentropyx Spix, 1825, Plica (Linnaeus, 1758), Polychrus Merrem, 1820, Dactyloa (Daudin, 1804) [= Anolis] and Ameiva Meyer, 1795 were infected by parasites of the referred genus (Ávila \& Silva 2010). We recorded a specimen Piratuba sp. infecting Gymnodactylus geckoides, which corresponds to a new record for Piratuba.

Currently, there are 23 genera of helminths recognized as parasites of the lizard families Phyllodactylidae and Gekkonidae (Anjos et al. 2005; Ávila \& Silva 2010; Ávila et al. 2010; Avila \& Silva 2013; Brito et al. 2014a; Sousa et al. 2014; Cazorla \& Morales Moreno 2015; Bezerra et al. 2016; this study); for the Caatinga biome, about 10 species of helminths have already been reported with a prevalence above 50\% (Anjos et al. 2005; Avila et al. 2012; Brito et al. 2014b; Sousa et al. 2014; this study), and there were four helminth species with prevalences below $60 \%$ for deserts and coastal areas in Peru (Goldberg \& Bursey 2010); two species had prevalences of $33.3 \%$ in the Brazilian Amazon forest (Ávila \& Silva 2013); two species had prevalences up to $22.8 \%$ in the Atlantic Forest (Ávila et al. 2010; Almeida-Gomes et al. 2012); and three helminth species had prevalences below $15 \%$ for the tropical thorny mountain areas of Venezuela (Cazorla \& Morales Moreno 2015). Notwithstanding that some genera and species of helminths were previously reported for different biomes as parasites of geckos, as S. oxkutzcabiensis and all species of the genera Oochoristica and Parapharyngodon, almost all prevalences registered for them were below that obtained for the Caatinga biome [e.g., Oochoristica sp. and species of the genus Parapharyngodon presented up to $55 \%$ prevalence, while $S$. oxkutzcabiensis did not exceed $8 \%$ in coastal environments of the tropical thorny mountain areas in Peru and Venezuela (Goldberg \& Bursey 2010; Cazorla \& Morales Moreno 2015)]. These results suggest that the different environmental conditions of distinct biomes may favor one parasitic species over another, such as S. oxkutzcabiensis. The presence of Trichospirura in lizards of the genus Sceloporus in Mexico and H. brookii haitianus Meerwarth, 1901 in Hispaniola (Goldberg et al. 2003; Powell et al. 1990), suggests that the new host records documented here may not be species-specific of the studied biome. Therefore, additional studies are necessary in the different biomes to determine the true helminth diversity of these two families of lizards.

The current study increases to 16 the number of new host records in association with the families Phyllodactylidae and Gekkonidae in the Caatinga biome. However, the development of new research on other areas of the biome is essential to enhance our scientific knowledge of the diversity of helminths associated with lizards.

\section{Supplementary material}

The following online material is available for this article:

Appendix 1: Voucher specimens of helminth parasites and respective host lizards collected in the Aiuaba Ecological Station, northeastern Brazil.

\section{Acknowledgements}

We thank the support of the Coordenação de Aperfeiçoamento de Pessoal de Nível Superior (CAPES) for the scholarship of V.F. Lima, A.A.M. Teixeira, A.M.A. Pereira; and the Conselho Nacional de Desenvolvimento
Científico e Tecnológico - CNPq (PQ-302429/2015-8) for the research fellowship given to W.O. Almeida and scholarship to J.A. Araujo-Filho and D.A. Teles.

\section{Author Contributions}

Adonias Aphoena Martins Teixeira: contribution to data collection; contribution to identification of parasites and lizards; contribution to data analysis and interpretation; contribution to manuscript preparation and critical revision.

Antonio Marcos Alves Pereira: contribution to data collection; contribution to identification of parasites and lizards; contribution to data analysis and interpretation; contribution to manuscript preparation and critical revision.

Diêgo Alves Teles: contribution to data collection; contribution to identification of parasites and lizards; contribution to data analysis and interpretation; contribution to manuscript preparation and critical revision.

João Antonio Araujo Filho: contribution to data collection; contribution to identification of parasites and lizards; contribution to data analysis and interpretation; contribution to manuscript preparation and critical revision.

Samuel Cardozo Ribeiro: contribution to data collection; contribution to identification of parasites and lizards; contribution to data analysis and interpretation; contribution to manuscript preparation and critical revision.

Samuel Vieira Brito: contribution to data collection; contribution to identification of parasites and lizards; contribution to data analysis and interpretation; contribution to manuscript preparation and critical revision.

Vandeberg Ferreira Lima: contribution to data collection; contribution to identification of parasites and lizards; contribution to data analysis and interpretation; contribution to manuscript preparation and critical revision.

Waltécio de Oliveira Almeida: contribution to data collection; contribution to identification of parasites and lizards; contribution to data analysis and interpretation; contribution to manuscript preparation and critical revision.

\section{Conflicts of interest}

The authors declares that they have no conflict of interest related to the publication of this manuscript.

\section{References}

ALBUQUERQUE, N.R.D., COSTA-URQUIZA, A.D.S., SOARES, M.P., ALVES, L.S. \& URQUIZA, M.V.S. 2013. Diet of two sit-and-wait lizards, Phyllopezus pollicaris (Spix, 1825) (Phyllodactylidae) and Hemidactylus mabouia (Moreau de Jonnès, 1818) (Gekkonidae) in a perianthropic area of Mato Grosso do Sul, western Brazil. Biota Neotrop. 13(4):376-381. http://dx.doi.org/10.1590/ S1676-06032013000400032 (last access on 11/11/2015)

ALMEIDA-GOMES, M., VRCIBRADIC, D., MAIA-CARNEIRO, T. \& ROCHA, C.F.D. 2011. Diet and endoparasites of the lizard Gymnodactylus darwinii (Gekkota, Phyllodactylidae) from an Atlantic Rainforest area in southeastern Brazil. Biotemas 25(1):203-206. doi: 10.5007/2175-7925.2012v25n1p203 (last access on 09/05/2014)

ANDERSON, R.C. 2000. Nematode parasites of vertebrates: Their development and transmission. 2 ed. CABI International, Wallingford.

ANDRADE, M.J.M.D., SALES, R.F.D. \& FREIRE, E.M.X. 2013. Ecology and diversity of a lizard community in the semiarid region of Brazil. Biota Neotrop. 13(3):199-209. http://dx.doi.org/10.1590/S1676-06032013000300023 (last access on 22/04/2014)

ANDRADE-LIMA, D. 1981. The caatingas dominium. Rev. bras. bot. 4(1):149-163.

ANJOS, L.A., ROCHA, C.F.D., VRCIBRADIC, D. \& VICENTE, J.J. 2005. Helminths of the exotic lizard Hemidactylus mabouia from a rock outcrop area in southeastern Brazil. J. Helminthol. 79(4):307-313. http://dx.doi.org/10.1079/ JOH2005288 (last access on 22/04/2014)

ANJOS, L.A., BEZERRA, C.H., PASSOS, D.C., ZANCHI, D. \& GALDINO, C.A.B. 2011. Helminth fauna of two gecko lizards, Hemidactylus Agrius and 
Lygodactylus Klugei (Gekkonidae), from Caatinga biome, Northeastern Brazil. Neotrop. Helminthol. 5(2):285-290.

ANJOS, L.A., AVILA, R.W., RIBEIRO, S.C., ALMEIDA, W.O. \& SILVA, R.J. 2013. Gastrointestinal nematodes of the lizard Tropidurus hispidus (Squamata: Tropiduridae) from a semi-arid region of northeastern Brazil. J. Helminthol. 87(4):443-449. http://dx.doi.org/10.1017/S0022149X12000491. (last access on $22 / 04 / 2014$ )

ARAUJO FILHO, J.A., RIBEIRO, S.C., BRITO, S.V., TELES, D.A., SOUSA, J.G.G., ÁVILA, R.W. \& ALMEIDA, W.O. 2014. Parasitic nematodes of Polychrus acutirostris (Polychrotidae) in the Caatinga biome, Northeastern Brazil. Braz. J. Biol. 74(4):939-942. http://dx.doi.org/10.1590/1519-6984.01313 (last access on 10/06/2015)

ÁVILA, R.W. \& SILVA, R.J. 2010. Checklist of helminths from lizards and amphisbaenians (Reptilia, Squamata) of South America. J. Venom. Anim. Toxins. 16(4):543-572. http://dx.doi.org/10.1590/S1678-91992010000400005 (last access on 22/04/2014)

AVILA, R.W., ANJOS, L.A., GONÇALVES, U., FREIRE, E.M.X., ALMEIDA, W.O. \& DA SILVA, R.J. 2010. Nematode infection in the lizard Bogertia lutzae (Loveridge, 1941) from the Atlantic forest in north-eastern Brazil. J. Helminthol. 84(2):199-201. http://dx.doi.org/10.1017/S0022149X09990538 (last access on 22/04/2014)

ÁVILA, R.W., ANJOS, L.A., RIBEIRO, S.C., MORAIS, D.H., DA SILVA, R.J. \& ALMEIDA, W.O. 2012. Nematodes of lizards (Reptilia: Squamata) from Caatinga biome, northeastern Brazil. Comp. Parasitol. 79(1):56-63. http:// dx.doi.org/10.1654/4518.1 (last access on 22/04/2014)

AVILA, R.W. \& DA SILVA, R.J. 2013. Helminths of lizards from the municipality of Aripuana in the southern Amazon region of Brazil. J. Helminthol. 87(1):12-16.

BEZERRA, C.H., PINHEIRO, L.T., MELO, G.C.D., ZANCHI-SILVA, D., QUEIROZ, M.D.S., ANJOS, L.A.D. \& BORGES-NOJOSA, D.M. 2016. Assessing the influence of geographic distance in parasite communities of an exotic lizard. Acta Parasitol. 61(1):136-143. http://dx.doi.org/10.1515/ap-2016-0018 (last access on 15/12/2016)

BRITO, S.V., FERREIRA, F.S., RIBEIRO, S.C., ANJOS, L.A., ALMEIDA, W.O., MESQUITA, D.O. \& VASCONCELLOS, A. 2014a. Spatial-temporal variation of parasites in Cnemidophorus ocellifer (Teiidae) and Tropidurus hispidus and Tropidurus semitaeniatus (Tropiduridae) from Caatinga areas in northeastern Brazil. Parasitol. res. 113(3):1163-1169. http://dx.doi.org/10.1007/s00436-0143754-7 (last access on 12/03/2014)

BRITO, S.V., CORSO, G., ALMEIDA, A.M., FERREIRA, F.S., ALMEIDA, W.O., ANJOS, L.A., MESQUITA, D.O. \& VASCONCELLOS, A. 2014b. Phylogeny and micro-habitats utilized by lizards determine the composition of their endoparasites in the semiarid Caatinga of Northeast Brazil. Parasitol. res. 113(11):3963-3972. http://dx.doi.org/10.1007/s00436-014-4061 (last access on 12/03/2014)

BURSEY, C.R., GOLDBERG, S.R. \& TELFORD JR, S.R. 2003. Rhabdias anolis n. sp. (Nematoda: Rhabdiasidae) from the lizard, Anolis frenatus (Sauria: Polychrotidae), from Panama. J. Parasitol. 89(1):113-117. http://dx.doi. org/10.1645/0022-3395(2003)089[0113:RANSNR]2.0.CO;2 (last access on $22 / 04 / 2014)$

BURSEY, C.R. \& GOLDBERG, S.R. 2004. Helminths of Tropidurus guarani (Sauria: Tropiduridae) from Paraguay. Comp. Parasitol. 71(2):203-207. http:// dx.doi.org/10.1654/4105

BURSEY, C.R., GOLDBERG, S.R. \& PARMELEE, J.R. 2005. Gastrointestinal helminths from 13 species of lizards from Reserva Cuzco Amazónico, Peru. Comp. Parasitol. 72(1):50-68. http://dx.doi.org/10.1654/4132 (last access on 22/04/2014)

BUSH, A.O., LAFFERTY, K.D., LOTZ, J.M. \& SHOSTAK, A.W. 1997. Parasitology meets ecology on its own terms: Margolis et al. revisited. J. Parasitol. 83(4):575-583.

CAZORLA, D. \& MORALES MORENO, P. 2015. Parásitos intestinales de Thecadactylus rapicauda (Reptilia: Squamata, Phyllodactylidae) en Coro, estado Falcón, Venezuela. Rev. Científ. 25(4):346-351.

COLLI, G.R., MESQUITA, D.O., RODRIGUES, P.V. \& KITAYAMA, K. 2003. Ecology of the gecko Gymnodactylus geckoides amarali in a Neotropical savanna. J. Herpetol. 37(4):694-706.

COSGROVE, G.E., NELSON, B. \& GENGOZIAN, N. 1968. Helminth parasites of the tamarin, Saguinus fuscicollis. Lab. Anim. Care. 18(6):654-656.
COSTA H.C. \& BÉRNILS R.S. 2015. Répteis brasileiros: Lista de espécies. Herpetologia Brasileira 4(3):75-92.

EVERHART, B.A. 1957. Notes on the helminths of Pseudemys scripta elegans Wied, 1838 in areas of Texas and Oklahoma. Proc. Okla. Acad. Sci. 1(1):38-43.

FERGUSON, M.S. 1942. Development of the metacercariae of Diplostomum flexicaudum in the lenses of frogs, turtles, birds, and mammals. J. Parasitol. 28(6):1-9.

GALDINO C.A.B., ÁVILA R.W., BEZERRA C.H., PASSOS D.C., MELO G.C. \& ZANCHI-SILVA D. 2014. Helminths infection patterns in a lizard (Tropidurus hispidus) population from a semiarid Neotropical area: associations between female reproductive allocation and parasite loads. J. Parasitol. 100(6):864-867. http://dx.doi.org/10.1645/13-264.1 (last access on 06/06/2015)

GOLDBERG, S.R., BURSEY, C.R. \& CAMARILLO-RANGEL, J.L. 2003 Gastrointestinal helminths of seven species of Sceloporine lizards from Mexico. Southwest. Nat. 48(2):208-217. http://dx.doi.org/10.1894/00384909(2003)048<0208:GHOSSO > 2.0.CO;2 (last access on 04/04/2014)

GOLDBERG, S.R., BURSEY, C.R. \& VITT, L.J. 2010. Gymnodactylus geckoides (Naked-toed Gecko). Endoparasites. Herpetol. Rev. 41(2):223.

HAMANN, M.I., GONZÁLEZ, C.E. \& KEHR, A.I. 2006a. Helminth community structure of the oven frog Leptodactylus latinasus (Anura, Leptodactylidae) from Corrientes, Argentina. Acta. Parasitol. 51(4):294-299.

HAMANN, M.I., KEHR, A.I. \& GONZÁLEZ, C.E. 2006b. Species affinity and infracommunity ordination of helminths of Leptodactylus chaquensis (Anura: Leptodactylidae) in two contrasting environments from northeastern Argentina. J. Parasitol. 92(6):1171-1179.

IBGE (INSTITUTO BRASILEIRO DE GEOGRAFIA E ESTATÍSTICA). 2004. Mapa de biomas do Brasil: Primeira aproximação. Ministério do Meio Ambiente e IBGE, Diretoria de Geociências, Coordenação de Recursos Naturais e Estudos Ambientais, Brazil.

IPECE (Instituto de Pesquisa e Estratégia Econômica do Ceará). 2015. Perfil Básico Municipal: Aiuaba. Instituto de Pesquisa e Estratégia econômica do Ceará (IPECE). Fortaleza- Ceará. 1-18.

ILLGEN-WILCKE, B., BEGLINGER, R., PFISTER, R. \& HEIDER, K. 1992. Studies on the developmental cycle of Trichospirura leptostoma (Nematoda: Thelaziidae). Parasitol. res. 78(6): 509-512.

LENT, H. \& FREITAS, J.D. 1941. Sôbre os filarideos parasitos de lacertideos neotropicos. Rev. Bras. Biol. 1(4):383-386.

LHERMITTE, N., BAIN, O. \& HERING-HAGENBECK, S. 2007. Three species of Skrjabinelazia Sypliaxov, 1930 (Nematoda: Seuratidae) parasitic in Gekkonidae and Lacertidae from South Africa, Europe and Australia. Syst. parasitol. 67(2):125-137. http://dx.doi.org/10.1007/s11230-006-9090-2 (last access on 11/05/2015)

MARCOGLIESE, D.J. 2004. Parasites: small players with crucial roles in the ecological theater. EcoHealth 1(2):151-164. http://dx.doi.org/10.1007/s10393004-0028-3 (last access on 06/04/2014)

MARCOGLIESE, D.J. 2005. Parasites of the superorganism: are they indicators of ecosystem health? Inter. J. parasitol. 35(7):705-716. http://dx.doi.org/10.1016/j. ijpara.2005.01.015 (last access on 06/04/2014)

MCALLISTER, C.T., BURSEY, C.R. \& FREED, P.S. 2011. Endoparasites (Cestoidea, Nematoda, Pentastomida) of Reptiles (Sauria, Ophidia) from the Republic of Namibia. Comp. Parasitol. 78(1):140-151.

MENEZES, V.A., VRCIBRADIC, D., VICENTE, J.J., DUTRA, G.F. \& ROCHA, C.F 2004. Helminths infecting the parthenogenetic whiptail lizard Cnemidophorus nativo in a restinga habitat of Bahia State, Brazil. J. Helminthol. 78(4):323-328.

MESQUITA, D.O., COLLI, G.R., FRANÇA, F.G. \& VITT, L.J. 2006. Ecology of a Cerrado lizard assemblage in the Jalapão region of Brazil. Copeia 2006(3):460-471.

ORIHEL, T.C. \& SEIBOLD, H.R. 1971. Trichospirurosis in South American monkeys. J. Parasitol. 57(6):1366-1368.

PACHECO, L.R., NERI, F.M., FRAHIA, V.T. \& MELO, A.L. 2003. Parasitismo natural em sauás, Callicebus nigrifrons (Spix, 1823): Variação na eliminação de ovos de Nematoda e Cestoda. Neotrop. Primat. 11(1):29-32.

PASSOS, D.C., ZANCHI, D. \& DUARTE ROCHA, C.F. 2013. Basking in shadows and climbing in the darkness: microhabitat use, daily activity and thermal ecology of the gecko Phyllopezus periosus Rodrigues, 1986. Herpetozoa 25(3/4):171-174. 
PASSOS, D.C., BARBOSA GALDINO, C.A., BEZERRA, C.H. \& ZANCHISILVA, D. 2015. On the natural history of the poorly known Neotropical lizard Hemidactylus agrius (Squamata: Gekkonidae). North-Western J. Zool. 11(1):133-137.

PEREIRA, F.B., ALVES, P.V., ROCHA, B.M., LIMA, S.S. \& LUQUE, J.L. 2012. A new Physaloptera (Nematoda: Physalopteridae) parasite of Tupinambis merianae (Squamata: Teiidae) from Southeastern Brazil. J. Parasitol. 98(6):1227-1235. http://dx.doi.org/10.1645/GE-3159.1 (last access on 19/10/2015)

POWELL, R., HALL, P.J., GREVE, J.H. \& SMITH, D.D. 1990. Occurrence of Trichospirura teixeirai (Spirurida: Rhabdochonidae) in Hemidactylus brookii haitianus (Sauria: Gekkonidae) from Hispaniola. J. Helminthol. Soc. W. 57(1):74-75.

RECORDER, R., TEIXEIRA, M., CAMACHO, A. \& RODRIGUES, M.T. 2012. Natural history of the tropical gecko Phyllopezus pollicaris (Squamata, Phyllodactylidae) from a sandstone outcrop in Central Brazil. Herpetol. Notes 5(2012):49-58.

RESENDE, D.M.D., PEREIRA, L.H., MELO, A.L.D., TAFURI, W.L., MOREIRA, N.I.B. \& OLIVEIRA, C.L.D. 1994. Parasitism by Primasubulura jacchi (Marcel, 1857) Inglis, 1958 and Trichospirura leptostoma Smith and Chitwood, 1967 in Callithrix penicillata marmosets, trapped in the wild environment and maintained in captivity. Mem. Inst. Oswaldo Cruz 89(1):123-125.

ROCHA, C.F.D., ANJOS, L.A. \& BERGALLO, H.G. (2011). Conquering Brazil: the invasion by the exotic gekkonid lizard Hemidactylus mabouia (Squamata) in Brazilian natural environments. Zoologia (Curitiba) 28(6):747-754. http:// dx.doi.org/10.1590/S1984-46702011000600007 (12/10/2017)

ROUND, M.C. 1968. Check list of the helminth parasites of African mammals of the orders Carnivora, Tubulidentata, Proboscidea, Hyra-coidea, Artiodactyla and Perissodactyla. 1 ed. Farnham: Commonwealth Agricultural Bureaux, St. Albans.

SALGADO-MALDONADO, G., AGUILAR-AGUILAR, R., CABANASCARRANZA, G., SOTO-GALERA, E. \& MENDOZA-PALMERO, C. 2005. Helminth parasites in freshwater fish from the Papaloapan river basin, Mexico. Parasitol. res. 96(2):69-89. http://dx.doi.org/10.1007/s00436-005-1315-9 (last access on $02 / 06 / 2015$ )
SHARPILO, V.P., BISERKOV, V., KOSTADINOVA, A., BEHNKE, J.M. \& KUZMIN, Y.I. 2001. Helminths of the sand lizard, Lacerta agilis (Reptilia, Lacertidae), in the Palearctic: faunal diversity and spatial patterns of variation in the composition and structure of component communities. Parasitology 123(4):389-400. http://dx.doi.org/10.1017/S0031182001008587 (last access on $02 / 06 / 2015$ )

SITES JR, J.W., REEDER, T.W. \& WIENS, J.J. 2011. Phylogenetic insights on evolutionary novelties in lizards and snakes: sex, birth, bodies, niches, and venom. Annu. Rev. Ecol. Evol. Syst. 42(1):227-244. http://dx.doi.org/ 10.1146/ annurev-ecolsys-102710-145051 (last access on 02/06/2015)

SOUSA, P.A.G. 2010. Estrutura da Comunidade de Lagartos de um remanescente de mata atlântica do Estado do Rio Grande do Norte, Brasil. Dissertação de Mestrado. Universidade Federal do Rio Grande do Norte, Natal, Rio Grande do Norte.

SOUSA, J.G.G., BRITO, S.V., ÁVILA, R.W., TELES, D.A., ARAUJO-FILHO, J.A., TEIXEIRA, A.A.M., ANJOS, L.A. \& ALMEIDA, W.O. 2014. Helminths and Pentastomida of two synanthropic gecko lizards, Hemidactylus mabouia and Phyllopezus pollicaris, in an urban area in Northeastern Brazil. Braz. J. Biol. 74(4):943-948. http://dx.doi.org/10.1590/1519-6984.01413 (last access on $02 / 03 / 2015$ )

SMITH, W.N. \& CHITWOOD, M.B. 1967. Trichospirura leptostoma gen. et sp. n. (Nematoda: Thelazioidea) from the pancreatic ducts of the white-eared marmoset Callithrix jacchus. J. Parasitol. 53(6):1270-1272.

VICENTE, J.J., RODRIGUES, H.O., GOMES, D.C. \& PINTO R. M. 1993. Nematóides do Brasil. Parte III: Nematóides de Répteis. Rev. Bras. Zool. 10(1): 19-168.

VITT, L.J. 1995. The ecology of tropical lizards in the caatinga of northeast Brazil. Occasional Papers of the Oklahoma Museum of Natural History. 1(1995)1-29.

Received: 19/09/2016

Revised: 26/09/2017

Accepted: 01/10/2017

Published online: 26/10/2017 